\title{
Projecting Whiteness: Race and the Unconscious in the History of 19th-century American Workers*
}

\author{
Frank Towers
}

Historical writing on American workers offers scholars interested in the broader field of American culture a reference point from which to gauge the problems and prospects of some important trends in the field. American labor history has undergone several sweeping revisions since the 1960 s which correspond to similar changes elsewhere in the humanities and social sciences. In analyzing these changes, this essay pays particular attention to recent scholarly emphasis on "whiteness," or the social construction of racial identity, as an explanation for the history of the American working class. During the 1990s, the concept of whiteness has emerged as a category of analysis in American cultural studies. Some assessment of its origins in one field and the strengths and weaknesses of the concept as an analytical tool seem in order as the decade closes.

Since the late 1980 s, historians have grown pessimistic about the potential for the American working class to be the carriers of egalitarian and emancipatory social values. As a product of the times, this new pessimism reflects liberal disillusionment with the conservative politics of many white, ethnic trade union members, or Reagan Democrats, and the decline of unions and heavy industry as central features of America's political economy. Within the academy, the new skepticism about class-based social movements is an almost inevitable counterpoint to the rosy optimism of the New Labor History that emerged in the 1960 s and '70s and argued for a usable past of working-class struggle against inequality. One proof of that pessimistic counterpoint has been the deplorable record of racial exclusion practiced by white, usually all male, trade unions. The concept of whiteness as a social-historical discourse that structured action and identity has been invoked to explain this pattern of racial exclusion. The study of white workers' racial discourse has opened new avenues of research and brought to scholarly attention a fuller picture of divisions within the work force that fragmented class solidarity. But the pessimists have at times overstated their case, in part because of problems in the way they theorize collective identity and behavior. Scholars need to explain more carefully how the collective psychology of racial identity operates and attend to the hallmarks of good historical scholarship, i.e. local context and differences in the time and place of every event.

From the dawn of the fields of labor history and labor economics in the 1880 s until the mid-1960s, the most influential scholars in the field focused on the trade union and labor relations between unions and employers. What came to be known pejoratively as the "Old Labor History," provided a teleological narrative of workers' progress from early nineteenth-century debilitation caused by absent organization and misguided utopian politics to a triumphant present characterized by strong unions, tangible gains in working conditions and wages, and a respected place in the mainstream of society. For scholars like John R. Commons, Selig Perlman and Norman Ware, the history of American labor was the story of union development within the framework of capitalist market relations. ${ }^{1}$

In the $1960 \mathrm{~s}$, the rise of the New Left and an increased attention to the lives of those excluded from powerful political institutions transformed the field of labor history. This "New Labor History" drew inspiration from E. P. Thompson, whose 1964 Making of the English Working Class avoided the conventional focus on unions and rejected a definition of class as a pre-determined category identified in the objective, material conditions of people's relationship to the means of production. Calling for the study of the working class as a "social and cultural formation," Thompson defined class as "an historical phenomenon, unifying a number of disparate and seemingly unconnected events, both in the raw material of experience and in consciousness" $(9,11)$. In the United States, the New Labor History, most prominently associated with the work of Herbert Gutman, pursued this history of workers' consciousness, or, more accu- 
rately, culture, in areas outside of the trade union hall, and looked at the alternatives to craft unions that the Old Labor History dismissed as misguided anachronisms. The New Labor History worked with a more flexible definition of what a worker was, one that went beyond the archetypes of factory hands and skilled craftsmen to include shopkeepers, apprentices, slaves, and women working outside the wage economy. They challenged not only Commons, Perlman, and Ware, but also the 1950s consensus historians Louis Hartz and Richard Hofstadter, who claimed that class distinctions did not exist in U.S. history and that most people shared a common set of aspirations for material advancement and political liberty (Hartz, Hofstadter). Historians Alan Dawley, Thomas Dublin, Leon Fink, Gutman, Bruce Laurie, David Montgomery, Sean Wilentz and others amassed a mountain of evidence showing an oppositional culture to that of property owners and professionals. The New Labor History brought to life a past usable for 1960s New Left activists battling the politics and culture of the middle-class mainstream. ${ }^{3}$

Two works, one that pioneered the New Labor History and another that represented its maturation, have become emblems of the blindness of those scholars to discriminatory practices and hierarchical relationships within the work force. One of Gutman's early essays focused on inter-racial organizing by the United Mine Workers of America (UMW) in Alabama, one of the most anti-union and racially polarized areas of late-nineteenth century America. To show the egalitarian potential of American workers, Gutman seized upon the career of Richard L. Davis, an African-American who served on the UMW's national executive board in 1896 and 1897. Gutman claimed that Davis' prominence within the UMW and the union's policy of inter-racial organizing occurred because its leaders "deeply believed in the principle of human solidarity and in a kind of evangelical egalitarianism." Gutman's celebration of the UMW as "the most thoroughly integrated voluntary association in the United States of 1900" bolstered hopes of liberals like C. Vann Woodward that white workers would support civil rights by showing that even at the nadir of race relations in American history, forgotten alternatives of inter-racial solidarity could be found (Gutman, 1968: 83; Woodward, 1974). The radical past gave the lie to conservative claims that segregation was an immutable institution. ${ }^{4}$

In 1988, three years after Gutman's death, Herbert Hill, a white veteran of the Old Left who worked on labor issues for the NAACP before entering the academy, published a scathing attack on Gutman's inter- pretation of the UMW. Hill accused Gutman of "the failure to perceive the crucial significance of race consciousness in determining working class behavior and in influencing class relations." Hill persuasively showed the larger pattern of racial discrimination practiced by the UMW. Despite its official policy and the prominence of a handful of black organizers like Davis in its leadership, the top positions in the union remained in white hands. In the Deep South, where Gutman argued the UMW had been most courageous in defying Jim Crow, it segregated black and white locals. In districts without enough black miners to pose a credible threat as strikebreakers, the UMW restricted membership to whites only. On national issues, the UMW vigorously opposed Chinese immigration on the grounds that Asian labor degraded the status of white men. So much for "the principle of human solidarity" and "evangelical egalitarianism." In Hill's wake, a mix of radical long-time critics of the New Left and younger scholars piled on to the attack with article titles like "Myth Making as Labor History," "What Was So Great about Herbert Gutman?" and "The Gutman School; At What Intellectual Price?" They agreed with Nell Painter's charge that "the New Labor History has a race problem."s

A similar attack has been leveled against Sean Wilentz's Chants Democratic: New York City and the Rise of the American Working Class, 1788-1850. Published in 1984, Wilentz's ambitious, prize-winning study attempted to do for early U.S. workers what Thompson had done for those in England's industrial revolution. Echoing Thompson, Wilentz stated that "between 1829 ...and 1850, both a process and a strain of consciousness emerged...in which people came at various points to interpret social disorder and the decline of the Republic at least partly in terms of class divisions between capitalist employees and employers" (16-17). Wilentz celebrated the oppositional politics of labor reformers Thomas Skidmore and Frances Wright, workers in the General Trade Union, prolabor Loco Foco Democrats like Mike Walsh, and the plebeian culture of the fire companies, theaters, and taverns, a worldview encapsulated in the phrase "Bowery Republic." Especially noteworthy about Wilentz's work was his exploration of "artisan republicanism," a working-class variant on the political discourse of the Revolution $(257,295)$. Where the consensus historians of the 1950s had found an example of radicalism's limited appeal in the defeat of New York's Workingman's Party and a failed strike waged by the General Trade Union in the early 1830 s, Wilentz discovered a subterranean current of class 
struggle. He admitted that "measured by their grandest hopes the union had failed.... But," Wilentz contended "they also succeeded, despite the obstacles, in uniting craft workers as a class" (17).

As with Gutman, critics of Wilentz zeroed in on his silence on race. Noel Ignatiev called Chants Democratic, "The most egregious example of the blind spot of the New Labor Historians on race...by writing about white workers without reference to the black presence...[Wilentz] ignores one of the essential forces that shaped his subjects" (183). Wilentz omitted riots against blacks by white workers, the bloodiest of which occurred in the Civil War draft protest of 1863 , an event conveniently left out of his chronological sweep (Fried 400-03; Roediger, Towards 22, 3034). Wilentz also downplayed the racism and proslavery sympathies of the Loco Focos, especially Walsh. Worst of all, he ignored the actions of blacks within the working-class of New York, home to the fifth largest urban black population in 1850 (DeBow).

Ironically, New Labor Historians who denounced the reactionary politics they perceived in the work of their predecessors have now themselves occasionally been caricatured as a reactionary force within the intellectual left. Critics of the New Labor History also point out their comparative silence on gender and their naive linkage of political rhetoric to social relations, a charge forcefully prosecuted by proponents of post-structuralist linguistic theory. ${ }^{8}$ In the $1990 \mathrm{~s}$, critics of Gutman and Wilentz have written their own versions of American labor history with a heightened sensitivity to race. The first and most influential of these studies is David Roediger's The Wages of Whiteness, published in 1991. Roediger sought to show the ways that "whiteness" as a social-cultural discourse structured the behavior of white wage earners. He did so by analyzing diverse cultural phenomena such as minstrel shows and riots and the uses of terms like "white," "slave," "hireling," and "master." Roediger argued that white workingmen in the early 19th century lost skills and workplace autonomy in the face of industrial expansion. In order to compensate for the alienation and degradation they felt as hirelings in a republic that valued independence and mastery, white workers constructed an identity of whiteness that claimed independence and power for all those who shared the same skin type and projected dependency and license onto a black other. In Roediger's words, "the white working class, disciplined and made anxious by the fear of dependency, began during its formation to construct an image of the Black population as 'other'-as embodying the preindustrial, erotic, careless style of life the white worker hated and longed for" (Wages 14). In this formulation, "status and privileges conferred by race could be used to make up for alienating and exploitive class relationships" (Wages 13). White labor earned its social-psychological status by supporting wealthy white men who were their class enemies but racial allies. ${ }^{9}$

Roediger has been joined by some members of the Old Left like Hill and Alexander Saxton and newer scholars such as Eric Lott in bringing to the foreground of scholarly attention the negative, exclusionary side of the republican rhetoric that infused American political and social life in the century following independence. That valuable contribution has helped bring a more sober appraisal of why republicanism failed to extend the promised rights of the Declaration of Independence to all Americans, and it has re-directed historians attention away from the skilled, white, male worker, Marx's "labor aristocracy," and pointed them towards the unskilled, nonwhite, and female elements of the work force that today comprise its majority. ${ }^{10}$

In its intellectual lineage, the concept of whiteness resembles "herrenvolk democracy," a term pioneered by sociologist Pierre L. van den Berghe and historian George Fredrickson in the 1960s and '70s. Herrenvolk, or master race, democracy, described the dominance of a broad ruling class that treated its members equally without regard to internal distinctions. Ruling class equality depends on the exclusion of other groups, the basic category of division in America being race. Supporters of slavery used this exclusionary egalitarianism as a rationale for nonslaveowning whites to join them. ${ }^{.1}$

Whiteness differs from this older concept in the emphasis that its proponents give to language. Where Fredrickson and historian of the Revolution Edmund Morgan looked for a causal connection between social and economic relationships on the one hand and racial rhetoric on the other, Eric Lott, in Love and Theft, a study of blackface minstrelsy, reversed the order of these relationships. As Lott put it, "blackface...figured class - that its languages of race so invoked ideas about class as to provide displaced maps or representations for 'working-classness'" (68). In varying degrees, whiteness theorists employ the post-structuralist insight into "the materiality of language itself, the impossibility of simply referring it back to some primal anterior reality, 'social being,' the impossibility of abstracting experience from the language which structures its articulation," to quote Gareth StedmanJones (20). Put simply, the proponents of what we might call the "whiteness" thesis argue that the con- 
sciousness of class in America (the phenomenon that Gutman and his followers said needed more attention in the 1960s) was embedded in a discourse about race that pre-dated the rise of factory, waged labor. ${ }^{12}$

Some methodological problems in this theory call into doubt its explanatory power and weaken its critique of the New Labor History. The privileging of language creates difficulties in accounting for change over time. If discourse has its own autonomous existence, what within language propels it to change its terms? For historians of race and labor in America, some obvious chronological issues need to be addressed. Namely, where did the racialized discourse of class come from? If historians accept that white wage earners developed their understandings of their class situation from the ways that they learned about blacks, then they need to explain how a set of concepts more applicable to the rural world of farming and bound labor proved so readily adaptable to mobile wage earners in an urban setting. They also need to answer why white workingmen seized upon racial imagery to articulate their identity as opposed to other contemporary discourses about religion, European national origin, gender, or republicanism minus its racial emphasis.

Another problem of the whiteness paradigm is its monolithic portrayal of American labor history as a continuous process of racial exclusion. Counter-examples to this picture come to mind from every period. Morgan's American Slavery, American Freedom showed that in the seventeenth century, white Virginians had a more flexible understanding of race and did not equate race with slavery. In the colonial period, white and black servants sometimes joined forces in defying plantation owners. Jefferson's hypocrisy in declaring liberty and equality to be universal human rights in 1776 has become a classroom cliché. Less prominent in current re-tellings of the Revolution is the abolition of slavery in half the nation by 1800 . Scholars have found that white men employed in manual trades comprised a large number of the anti-slavery movement's rank-and-file supporters (Magdol, Jentz). As racist as many free soil Republicans could be, some accounting must be taken of the more than 330,000 white men who gave their lives in the Civil War to end slavery. Hill's assessment of Gutman's romanticism aside, Davis held high office in the UMW and many blacks sought to join that union. Nor can Hill erase the existence of interracial organizing in the Knights of Labor, the largest labor organization of the 19 th century, or inter-racial locals in early 20 th-century longshoring, or the inter- racial organizing of the Congress of Industrial Organizations (CIO) in the 1930s (Fink, Workingmen's; Arnesen, Waterfront Workers; Goldfield). Some white-led unions joined the civil rights movement in the 1950s and '60s (Levy). Today, the AFL$\mathrm{CIO}$, led by its white president John Sweeney, has turned its attention to organizing non-white, female work forces in health care, hotel work, construction, and so on. These examples of inter-racial solidarity should not be taken as a starting point for a "no they weren't racists" counter-attack. More often than not white workers and white-led unions were hostile to non-whites. But the existence of so many white workers who wanted to ally with their black colleagues defies a uniform explanation of their behavior through a discourse of racial exclusion. ${ }^{13}$

Proponents of the whiteness thesis answer these criticisms in a variety of ways. Some, particularly Hill, try to debunk each of the above examples as either inconsequential or more the product of black agency and upper-class whites rather than workers. The scholars who lean on a post-structuralist explanation of discourse have had more influence and offer a way out of a tit-for-tat compilation of examples that support either side. The degree to which these scholars employ post-structuralist theory varies, with the most emphasis given by Lott. Yet the Freudian theory of psychic projection is common to the way these works explain the mechanism by which white workingmen came to perceive themselves to be white first and foremost and in turn viewed blacks as other. White workers are forced by their subordination to capitalist employers to renounce instinctual drives that Freud located in the Id; the main urges are the desire to play, negated by the discipline of the factory; the sensual, checked by bourgeois injunctions to channel erotic drives into hard work; and the aggressive reaction against authority imposed initially by parents and later by the boss. As Freud argued, humanity cannot prevent the "return of the repressed." Adopting this notion, studies of whiteness interpret minstrelsy, white-on-black violence, and the appropriation, often with negative connotations, of black culture as an expression of "hatred toward the object of desire," or a simultaneous lampooning of blacks and an effort to commune with repressed psychological urges that white men had projected onto them (Roediger, Wages 14-15, quotation 124). In his most Freudian moment, Lott writes that "because of the power of the black penis in American psychic life, the pleasure minstrelsy's largely white and male audiences derived from their investment in 'blackness' always carried a threat of castration" $(9$, also $6,70-71)$. 
The following passage from Sigmund Freud's The Future of an Illusion, written in 1927, sounds like the race-as-compensation argument of the whiteness historians.

The narcissistic satisfaction provided by the cultural ideal is also among the forces which are successful in combating the hostility to culture within the cultural unit. The satisfaction can be shared in not only by the favored classes...but also by the suppressed ones, since the right to despise the people outside it compensates them for the wrongs they suffer within their own unit. No doubt one is a wretched plebeian, harassed by debts and military service; but, to make up for it, one is a Roman citizen, one has one's share in the task of ruling other nations and dictating their laws. (Freud 13)

Applications of the explanation of white racism as a collective psychological response to modern society pre-date post-structuralism and have appeared in many forms in the study of race in American history. Winthrop Jordan and George Rawick used the idea to account for the origins of slavery. French sociologist Frantz Fanon, literary critic Leslie Fiedler, W. E. B. DuBois and even Frederick Douglass, who lived before Freud's time, argued that white men compensated for inequalities amongst themselves by stigmatizing blacks with even greater badges of inferiority. ${ }^{16}$

Psycho-analytic critiques offer a version of the compelling modernist drama of the rational subject's struggle for mastery. Freud probed the dark, romantic side of that struggle, but in the end scholars are left in a modernist box of examining the ways that white men constituted themselves as autonomous subjects. This story, as some of the same proponents of whiteness have pointed out, ignores the agency of nonwhites and women, characters frequently absent from the works discussed herein, and it unintentionally denies its subjects, white workingmen, much agency in becoming a unified pack of racists. In its explanation of historical change, the projection theory relies on an historical watershed during the industrial revolution when capitalists, acting like a punishing superego, took away the freedoms of craft producers who then created whiteness as a consolation (Roediger, Wages 14). That explanation assumes a monolithic white working class that was aesthetically sensitive but politically ignorant. These men found enough satisfaction in performances of blacks as other to overlook the stunning defeat inflicted by the bosses who closed routes to self-employment, drove down wages, divided tasks, and dominated government. ${ }^{17}$
The evidence contradicts such pat answers. On the issue of exploitation, numerous studies document collective resistance to factory discipline by small producers, and some show that families on the margins of survival welcomed factory work as a liberating alternative or as an income supplement useful in keeping family farms solvent. Furthermore, the work force of the early factory was more female and child than it was male and adult. ${ }^{18}$ Given the logic of projection, one would expect white women to have been the principal patrons of minstrel shows and the leaders of race riots.

Economic historians have long since exploded the notion of a uniform industrial revolution sweeping away self-employed craft workshops, non-wage home production and bound labor. Factory wage labor coexisted with artisan production long into the nineteenth century, and in the eyes of some scholars, the factory and its labor system is not a necessary feature of an industrial economy. Factories made the least headway in New York, Philadelphia, and other metropolitan centers, the homes of the racist Loco Foco Democrats, minstrel performers, and race rioters that support the case for whiteness. ${ }^{8}$

While the number of wage laborers, and hence dependent workers, grew in these cities, recent studies of nineteenth-century politics show that artisans and petty proprietors made up the majority of the electorate, and probably were the supporters of Loco Foco Democrats and Workingman's politicians like Walsh." If manual laborers had not been thoroughly subordinated to factory bosses, did they still need to repress their instincts and project them onto an "other?" The lives of urban white workers in the mid-nineteenth century offer abundant examples that they did not. Libidinous, unrepressed behavior manifested itself in riots at elections and on public holidays, prize fights, out-of-wedlock births and sexual promiscuity, and rising living wages that were spent on an unprecedented amount of meat and alcohol, commodities scarce in the lives of the eighteenth-century lower sort and the emigrating Irish peasantry. These facets of workingmen's lives suggest that instead of feeling repressed, they were having a good time, albeit not a respectable one by the standards of most late twentieth-century commentators or nineteenth-century middle-class observers. ${ }^{21}$ Studies of black life in nineteenth-century cities show that paternalistic alliances with wealthy whites were crucial in getting jobs and financing community projects like church building. ${ }^{22}$ White artisans able to vote and independent of factory owners for their livelihoods probably felt less pressure 
to conform to upper-class behavioral norms than did African-American domestic servants and skilled workers employed by white bosses but threatened by coercive laws that did not apply to their white competitors. This is not to say that white labor avoided racist behavior because it had more freedom than blacks, but it calls into question the explanation for racist behavior offered in the projection scenario.

Those who take issue with the pessimistic assessment of workers' willingness to form class-based movements that overcame racial divisions argue for the ebb and flow of interracial alliances rather than uniform racial opposition. Their general line of interpretation follows that of Ira Berlin and Herbert Gutman in their 1983 analysis of white and black labor in slave-state cities. Aware that "conflict among immigrant, native-born, and black workers divided working people," Berlin and Gutman wrote that "if free workers were pulled in all directions, their allegiance to the slave regime was never firm" (1197). The current literature on whiteness at times threatens to eclipse from historical sight challenges to slave owners and their urban allies that workers staged in the nineteenth century. ${ }^{12}$

Like most scholarly debates, the optimist/pessimist argument over white workingmen's radical potential might end by moving on to new questions rather than with one side having the last word. Students of the history of American workers might more profitably understand that past and convey it to others by taking up the recommendation of Eric Arnesen to study the "multitude of working-class race relations," or to look for the ways that local circumstances promoted inter-racial solidarity at certain moments and inhibited it at others (Arnesen, "Following" 56). The post-structuralist innovations of the whiteness interpretation have opened valuable avenues for research into workers' discourse, and this research has given an added spur to the study of nonwhite and female workers. This research agenda can be furthered by keeping in mind familiar historical questions: Who did what, when, where and to whom? In their search for interpretive models, historians have mainly been borrowers from other disciplines. History offers the humanities and social sciences a big bag of test cases for theories worked out within the tighter methodological boundaries of other fields. Tests of the psycho-analytic assumptions of whiteness call into question its uniform application to American culture. For scholars interested in the past of working-class Americans because those men and women have carried forward important and inspiring social changes, further exploration of whiteness might restore some optimism about working-class egalitarianism while keeping in mind the many divisions among workers that have inhibited it.

A version of this article was presented at the Ege University Cultural Studies Seminar 13-15 May 1998, Izmir, Turkey.

\section{Notes}

'Also known as the Commons School, or Wisconsin School, some major works of the Old Labor History are John R. Commons, David J. Saposs, Helen L. Sumner, E. B. Mittelman, H. E. Hoagland, John B. Andrews, and Selig Perlman, History of Labour in the United States (New York: The MacMillan Company, 1918-35); Norman Ware, The Industrial Worker, 1840-1860 (1924 rpt., Chicago: Ivan R. Dee, 1990); Selig Perlman, A Theory of the Labor Movement (New York: MacMillan, 1928); Philip Taft, The A.F. of L. from the Death of Gompers to the Merger (New York: Harper, 1959).

${ }^{2}$ Herbert Hill, "Myth-Making as Labor History: Herbert Gutman and the United Mine Workers of America," Journal of International Politics, Culture, and Society 2.2 (Winter 1988): 132-200; also see Herbert Hill, "Race, Ethnicity and Organized Labor: The Opposition to Affirmative Action," New Politics 1.2 (Winter 1987): 3182; Hill, "The Problem of Race in American Labor History," Reviews in American History 24.2 (June 1996): 189-208.

Hill's "Myth Making as Labor History" sparked a roundtable of replies in the next issue of the Journal of International Politics, Culture, and Society 2.3 (Spring 1989). See Steven Schulman, "Racism and the Making of the American Working Class," 361-66; Nell Irvin Painter, "The New Labor History and the Historical Moment," 367 70; David Roediger, "History Making and Politics," 37173; Martin Glaberman, "Workers Versus Unions in the Coal Industry," 373-77; Francille Rusan Wilson, "Black Workers Ambivalence Toward Unions," 378-81; Stephen Brier, "In Defense of Gutman; The Union's Case," 382-95; Irving Bernstein, "Herbert G. Gutman as Labor Historian," 396-99; and Albert Fried, "The Gutman School; At What Intellectual Price," 400-03. A similar round of commentary followed Hill's article in New Politics 2.3 (Summer 1988).

Also see David Roediger, "What Was so Great About Herbert Gutman?" Labour/Le Travailleur 23 (Spring 1989): 255-61; Lawrence T. McDonald, “'You Are Too Sentimental': Problems and Suggestions for a New Labor History," Journal of Social History 17 (Summer 1984): 629-53; Elizabeth Fox-Genovese and Eugene D. Genovese, 
"The Debate Over Time on the Cross: A Critique of Bourgeois Criticism," Fruits of Merchant Capital: Slavery and Bourgeois Property Relations in the Rise and Expansion of Capitalism (New York: Oxford UP, 1983) 143.

${ }^{3}$ For an introduction to gendered criticism of the New Labor History see Ava Baron, ed., Work Engendered: Toward a New History of American Labor (Ithaca, NY: Cornell UP, 1991), especially Baron's introduction, 1-46; Betina Bradbury, "Women's History and Working Class History," Labour/Le Travail 19 (Spring 1987): 23-41; Sally Alexander, "Women, Class, and Sexual Difference," History Workshop 17 (Autumn 1984): 125-46; Alice Kessler-Harris, "A New Agenda for American Labor History: A Gendered Analysis and the Question of Class," Perspectives on American Labor History: The Problem of Synthesis, J. Carroll Moody and Alice Kessler-Harris, eds. (DeKalb: Northern Illinois UP, 1989); Leon Fink, "Culture's Last Stand? Gender and the Search for Synthesis in American Labor History," Labor History 34 (Fall 1993): 178-89.

Influential in the genesis of whiteness studies have been works by African-American women who interrogated racism within feminism. See bell hooks, Ain't I a Woman? (Boston: South End Press, 1981); more recently, Toni Morrison, Playing in the Dark: Literature and the White Imagination (New York: Vintage, 1992).

For scholars seeking a more theoretically informed view of the role of language in labor history see Joan Wallach Scott, Gender and the Politics of History (New York: Columbia UP, 1988) and Gareth Stedman Jones, Languages of Class: Studies in English Working Class History, 1832-1982 (Cambridge: Cambridge UP, 1983).

${ }^{4}$ For other examples of this argument, see Eric Lott, Love and Theft: Blackface Minstrelsy and the American Working Class (New York: Oxford UP, 1993); Roediger, "What if Labor Were Not White and Male? Recentering Working-Class History and Reconstructing Debate on the Unions and Race," International Labor and Working-Class History 51 (Spring 1997): 72-95; Roediger, "Notes on Working-Class Racism," Towards the Abolition of Whiteness (London: Verso, 1994) 61-67; Ignatiev, How the Irish Became White; Neil Foley, The White Scourge: Mexicans, Blacks and Poor Whites in Texas Cotton Culture (Berkeley: U of California P, 1997); Tomas Almaguer, Racial Fault Lines: The Historical Origins of White Supremacy in California (Berkeley: U of California P, 1994); Theodore W. Allen, The Invention of the White Race: Volume One: Racial Oppression and Social Control (London: Verso, 1994) 199; Michael K. Honey, Southern Labor and Black Civil Rights: Organizing Memphis Workers (Urbana: U of Illinois P, 1993) 20; Alexander Saxton, The Rise and Fall of the White Republic: Class
Politics and Mass Culture in Nineteenth-Century America (London: Verso, 1990).

For an example of historians outside of labor history using the concept of whiteness, see Mary P. Ryan, Civic Wars: Democracy and Public Life in the American City During the Nineteenth Century (Berkeley: U of California P, 1997) 171; Angela Woolacott, " 'All This Is the Empire, I Told Myself': Australian Women's Voyages 'Home' and the Articulation of Colonial Whiteness," American Historical Review 102 (Oct. 1997): 1003-29; Cheryl I. Harris, "Whiteness as Property," Harvard Law Review 106 (1993): 1709-91; especially interesting is Mike Hill, ed., Whiteness: A Critical Reader (New York: New York UP, 1997).

${ }^{5}$ George M. Fredrickson, White Supremacy: A Comparative Study in American and South African History (New York: Oxford UP, 1981) 154-56; George M. Fredrickson, The Arrogance of Race: Historical Perspectives on Slavery, Racism, and Social Inequality (Middletown, CT: Wesleyan UP, 1988) 201, 204; a similar argument is presented in Edmund S. Morgan, American Slavery, American Freedom: The Ordeal of Colonial Virginia (New York: Norton, 1975) 369-70; James Oakes, The Ruling Race: A History of American Slaveholders (New York: Knopf, 1982) 141; the problems of the term are considered in Roediger, The Wages of Whiteness 59-60.

In many ways these explanations merely update work presented decades earlier. See Alexander Saxton, "Blackface Minstrelsy and Jacksonian Ideology," American Quarterly 27.1 (March 1975): 3-28; Richard Slotkin, Regeneration Through Violence: The Mythology of the American Frontier, 1600-1860 (Middletown, CT: Wesleyan UP, 1973) 22, 309; Slotkin, The Fatal Environment: The Myth of the Frontier in the Age of Industrialism, 1800-1890 (Middletown: Wesleyan UP, 1985) $139,150$.

'Gary Kulik, "Dams, Fish, and Farmers: Defense of Public Rights in Eighteenth-Century Rhode Island," The Countryside in the Age of Capitalist Transformation: Essays in the Social History of Rural America, ed. Stephen Hahn and Jonathan Prude (Chapel Hill: U of North Carolina P, 1985) 25-50; Paul Salstrom, Appalachia's Path to Dependency: Rethinking a Region's Economic History, 1730-1940 (Lexington: UP of Kentucky, 1994); Thomas Dublin, Transforming Women's Work: New England Lives in the Industrial Revolution (Ithaca: Cornell UP, 1994); Dublin, Women at Work; Jonathan Prude, The Coming of Industrial Order: Town and Factory Life in Rural Massachusetts (Cambridge: Cambridge UP, 1983).

${ }^{8} \mathrm{~A}$ good overview of the history of factories is Jonathan Prude, "Capitalism, Industrialization, and the Factory in Post-Revolutionary America," Wages of Independence: Capitalism In the Early American Republic 
ed. Paul A. Gilje (Madison, WI: Madison House, 1997) 81100; also see Wilentz, Chants Democratic; Laurie, Working People of Philadelphia; Bruce Laurie and Mark Schmitz, "Manufacture and Productivity: The Making of an Industrial Base, Philadelphia 1850-1880," Philadelphia: Work, Space, Family, and Group Experience in the 19th Century, ed. Theodore Hershberg (New York: Oxford UP, 1981) 43-92; Philip Scranton, Proprietary Capitalism: The Textile Manufacture at Philadelphia, 1800-1885 (Cambridge: Cambridge UP, 1983); Clyde and Sally Griffen, Natives and Newcomers: The Ordering of Opportunity in Mid-Nineteenth Century Poughkeepsie (Cambridge, MA: Harvard UP, 1978); Richard B. Stott, Workers in the Metropolis: Class, Ethnicity, and Youth in Antebellum New York City (Ithaca: Cornell UP, 1990).

${ }^{9}$ Philip J. Ethington, The Public City: The Political Construction of Urban Life in San Francisco, 1850-1900 (Cambridge: Cambridge UP, 1994) 47-58; Kenneth Winkle, The Politics of Community: Migration and Politics in Antebellum Ohio (Cambridge: Cambridge UP, 1988) 117-18; Paul Bourke and Donald DeBats, Washington County: Politics and Community in Antebellum America (Baltimore: Johns Hopkins UP, 1995) 240, 242; Amy Bridges, A City in the Republic: Antebellum New York and the Origins of Machine Politics (1984) (Ithaca: Cornell UP, 1987) $56,59$.

${ }^{10} B$ illy G. Smith, The "Lower Sort": Philadelphia's Laboring People, 1750-1800 (Ithaca: Cornell UP, 1990); Stott, Workers in the Metropolis 176-77; Richard B. Stott, ed., History of My Own Time, or, the Life and Adventures of William Otter, Sen. (Ithaca: Cornell UP, 1995); Elliott J. Gorn, "Good-Bye Boys, I Die a True American': Homicide, Nativism and Working-Class Culture in Antebellum New York City," Journal of American History 74 (Sept. 1987): 388-410; Christine Stansell, City of Women: Sex and Class in New York, 1789-1860 (Urbana: U of Illinois P, 1987).

"Shane White, Somewhat More Independent: The End of Slavery in New York City, 1780-1810 (Athens: U of Georgia P, 1991) 167; Ira Berlin, Slaves Without Masters: The Free Negro in the Antebellum South (New York: The New Press, 1974) 340; Leon Litwack, North of Slavery: The Negro in the Free States, 1790-1860 (Chicago: U of Chicago P, 1961) 279.

${ }^{12}$ For some of these works see Arnesen, Waterfront Workers of New Orleans; Arnesen, "Following the Color Line: Black Workers and the Labor Movement Before 1930," Radical History Review 55 (1993): 53-87; Arnesen, “'Like Banquo's Ghost, It Will Not Down': The Race Question and the American Railroad Brotherhoods, 1880 1920," American Historical Review 99 (Dec. 1994): 160133; Alex Lichtenstein, "Racial Conflict and Racial Solidarity in the Alabama Coal Strike of 1894: New
Evidence for the Gutman-Hill Debate," Labor History 36.1 (Winter 1995): 63-76; Barbara Jeanne Fields, "Ideology and Race in American History," Region, Race, and Reconstruction: Essays in Honor of C. Vann Woodward, ed. J. Morgan Kousser and James M. McPherson (New York: Oxford UP, 1982) 143-79; Robin D. G. Kelley, Hammer and Hoe: Alabama Communists During the Great Depression (Chapel Hill: U of North Carolina P, 1990); Evelyn Brooks Higginbotham, "African-American Women's History and the Metalanguage of Race," Signs 17 (1992): 251-74; Rick Halpern, Down on the Killing Floor: Black and White Workers in Chicago's Packinghouses, 1904-54 (Urbana: U of Illinois P, 1997); Iver Bernstein, The New York City Draft Riots: Their Significance for American Society and Politics in the Age of the Civil War (New York: Oxford UP, 1990) 5-6, 120; Larry J. Griffin and Robert R. Korstad, "Class as Race and Gender: Making and Breaking a Labor Union in the Jim Crow South," Social Science History 19.4 (Winter 1995): 425-54.

\section{Works Cited}

Alexander, Sally. "Women, Class, and Sexual Difference." History Workshop 17 (1984): 125-46.

Allen, Theodore $\mathrm{W}$. The Invention of the White Race: Volume One: Racial Oppression and Social Control. London: Verso, 1994.

Almaguer, Tomas. Racial Fault Lines: The Historical Origins of White Supremacy in California. Berkeley: U of California P, 1994.

Arnesen, Erik. "Following the Color Line: Black Workers and the Labor Movement Before 1930." Radical History Review 55 (1993): 53-87.

—. "'Like Banquo's Ghost, It Will Not Down': The Race Question and the American Railroad Brotherhoods, 1880-1920." American Historical Review 99 (1994): 1601-33.

- Waterfront Workers of New Orleans: Race, Class, and Politics, 1863-1923. Urbana: U of Illinois P, 1991.

Baron, Ava Baron, ed. Work Engendered: Toward a New History of American Labor. Ithaca: Cornell UP, 1991.

Berlin, Ira, and Herbert G. Gutman. "Natives and Immigrants, Free Men and Slaves: Urban Workingmen in the Antebellum American South." American Historical Review 88 (1983): 1175-1200.

- Slaves Without Masters: The Free Negro in the Antebellum South. New York: New Press, 1974.

Bernstein, Iver. The New York City Draft Riots: Their Significance for American Society and Politics in the Age of the Civil War. New York: Oxford UP, 1990.

Bourke, Paul, and Donald DeBats. Washington County: Politics and Community in Antebellum America. Baltimore: Johns Hopkins UP, 1995. 
Bradbury, Betina. "Women's History and Working Class History," Labour/Le Travail 19 (1987): 23-41.

Bridges, Amy. A City in the Republic: Antebellum New York and the Origins of Machine Politics. 1984. Ithaca: Cornell UP, 1987.

Commons, John R., David J. Saposs, Helen L. Sumner, E. B. Mittelman, H. E. Hoagland, John B. Andrews, and Selig Perlman. History of Labour in the United States. New York: Macmillan Co., 1918-1935.

Dawley, Alan. Class and Community: The Industrial Revolution in Lynn. Cambridge, MA: Harvard UP, 1977.

DeBow, J. D. B. The Seventh Census of the United States: 1850. Washington: Robert Armstrong, 1853.

Douglass, Frederick. "My Bondage and My Freedom." Autobiographies. 1845. New York: Library of America, 1994.

Dublin, Thomas. Transforming Women's Work: New England Lives in the Industrial Revolution. Ithaca: Cornell UP, 1994.

- Women at Work: The Transformation of Work and Community in Lowell, MA, 1826-1860. New York: Columbia UP, 1979.

DuBois, W. E. B., ed. The Negro American Artisan. 1921. New York: Arno Press, 1968.

Ethington, Philip J. The Public City: The Political Construction of Urban Life in San Francisco, 18501900. Cambridge: Cambridge UP, 1994.

Fanon, Frantz. Black Skins, White Masks. 1952. New York: Grove, 1967.

Feidler, Leslie. Waiting for the End. 1966. New York: Stein and Day, 1972.

Fields, Barbara Jeanne. "Ideology and Race in American History." Region, Race, and Reconstruction: Essays in Honor of C. Vann Woodward. Ed. J. Morgan Kousser and James M. McPherson. New York: Oxford UP, 1982.

Fink, Leon. "Culture's Last Stand? Gender and the Search for Synthesis in American Labor History." Labor History 34 (1993): 178-79.

- Workingmen's Democracy: The Knights of Labor and American Politics. Urbana: U of Illinois P, 1983.

Foley, Neil. The White Scourge: Mexicans, Blacks, and Poor Whites in Texas Cotton Culture. Berkeley: U of California P, 1997.

Fox-Genovese, Elizabeth, and Eugene D. Genovese. Fruits of Merchant Capital: Slavery and Bourgeois Property Relations in the Rise and Expansion of Capitalism. New York: Oxford UP, 1983.

Frederickson, George M. The Arrogance of Race: Historical Perspectives on Slavery, Racism, and Social Inequality. Middletown, CT: Wesleyan UP, 1988.
-White Supremacy: A Comparative Study in American and South African History. New York: Oxford UP, 1981.

Freud, Sigmund. "The Future of an Illusion." The Complete Psychological Works of Sigmund Freud. Vol. XXI. 1927. Ed. James Strachey and Anna Freud. London: Hogarth Press, 1961.

Fried, Albert. "The Gutman School; At What Intellectual Price.” New Politics 2 (1988): 400-03.

Goldfield, Michael. "Race and the CIO: The Possibilities for Racial Egalitarianism During the 1930s and 1940s." International Labor and Working Class History 44 (1993): 1-32.

Gorn, Elliott J. “ 'Good-Bye Boys, I Die a True American': Homicide, Nativism and Working-Class Culture in Antebellum New York City." Journal of American History 74 (1987): 388-410.

Griffen, Clyde, and Sally Griffen. Natives and Newcomers: The Ordering of Opportunity in Mid-Nineteenth Century Poughkeepsie. Cambridge, MA: Harvard UP, 1978.

Griffin, Larry J., and Robert R, Korstad. "Class as Race and Gender: Making and Breaking a Labor Union in the Jim Crow South." Social Science History 19 (1995): 425-54.

Gutmann, Herbert G. "The Negro and the United Mine Workers of America, The Career and Letters of Richard L. Davis and Something of their Meaning." The Negro and the American Labor Movement. Ed. Julius Jacobson. Garden City, NJ: Anchor Books, 1968.

--. Work, Culture, and Society in Industrializing America: Essays in American Working-Class and Social History. New York: Vintage Books, 1977.

Halpern, Rich. Down on the Killing Floor: Black and White Workers in Chicago's Packinghouses, 1904-54. Urbana: U of Illinois P, 1997.

Harris, Cheryl I. "Whiteness as Property." Harvard Law Review 106 (1993): 1709-91.

Hartz, Louis. The Liberal Tradition in America: An Interpretation of American Political Thought since the Revolution. New York: Harcourt Brace, 1955.

Higginbotham, Evelyn Brooks. "African-American Women's History and the Metalanguage of Race." Signs 17 (1992): 251-74.

Hill, Herbert. "Myth-Making as Labor History: Herbert Gutman and the United Mine Workers of America." Journal of Intemational Politics, Culture, and Society 2 (1988): 132-200.

-. "The Problem of Race in American Labor History." Reviews in American History 24 (1996): 189-208.

-. "Race, Ethnicity and Organized Labor: The Opposi- 
tion to Affirmative Action." New Politics 1 (1987): 3182.

Hill, Mike, ed. Whiteness: A Critical Reader. New York:

New York UP, 1997.

Hofstadter, Richard. The Age of Reform: From Bryan to F.D.R. New York: Knopf, 1963.

Honey, Michael K. Southern Labor and Black Civil Rights: Organizing Memphis Workers. Urbana: U of Illinois P, 1993.

hooks, bell. Ain't I a Woman? Boston: South End Press, 1992.

Ignatiev, Noel. How the Irish Became White. New York: Routledge, 1995.

Jentz, John B. "The Antislavery Constituency in Jacksonian New York City." Civil War History 27 (1981): 101-22.

Jordan, Winthrop D. White over Black: American Attitudes toward the Negro, 1550-1812. Chapel Hill: U of North Carolina P, 1968.

Journal of International Politics, Culture, and Society 2 (1989): 361-403.

Kelley, Robin D. G. Hammer and Hoe: Alabama Communists During the Great Depression. Chapel Hill: U of North Carolina P, 1990.

Kessler-Harris, Alice. "A New Agenda for American Labor History." Perspectives on American Labor History: The Problem of Synthesis. Ed. J. Carroll Moody and Alice Kessler-Harris. DeKalb: Northern Illinois UP, 1989.

Kulik, Gary. "Dams, Fish, and Farmers: Defense of Public Rights in Eighteenth-Century Rhode Island." The Countryside in the Age of Capitalist Transformation: Essays in the Social History of Rural America. Ed. Stephen Hahn and Jonathan Prude. Chapel Hill: U of North Carolina P, 1985.

Laurie, Bruce. Working People of Philadelphia, 1800-1850. Philadelphia: Temple UP, 1980.

Laurie, Bruce, and Mark Schmitz. "Manufacture and Productivity: The Making of an Industrial Base, Philadelphia 1850-1880." Philadelphia: Work, Space, Family, and Group Experience in the 19th Century. Ed. Theodore Hershberg. New York: Oxford UP, 1981.

Levy, Peter B. The New Left and Labor in the 1960s. Urbana: U of Illinois P, 1994.

Lichtenstein, Alex. "Racial Conflict and Racial Solidarity in the Alabama Coal Strike of 1894: New Evidence for the Gutman-Hill Debate." Labor History 36 (1995): 63-76.

Litwack, Leon. North of Slavery: The Negro in the Free States, 1790-1860. Chicago: U of Chicago P, 1961.

Lott, Eric. Love and Theft: Blackface Minstrelsy and the American Working Class. New York: Oxford UP, 1993.
Magdol, Edward. The Antislavery Rank and File: a Social Profile of the Abolitionists' Constituency. New York: Greenwood Press, 1986.

McDonald, Lawrence T. “'You Are Too Sentimental': Problems and Suggestions for a New Labor History." Journal of Social History 17 (1984): 629-53.

Montgomery, David. Workers' Control in America. Cambridge: Cambridge UP, 1974.

Morgan, Edmund S. American Slavery, American Freedom: The Ordeal of Colonial Virginia. New York: Norton, 1975.

Morrison, Toni. Playing in the Dark: Literature and the White Imagination. New York: Vintage Books, 1992.

Oakes, James. The Ruling Race: A History of American Slaveholders. New York: Knopf, 1982.

Perlman, Selig. A Theory of the Labor Movement. New York: MacMillan, 1928.

Prude, Jonathan. "Capitalism, Industrialization, and the Factory in Post-Revolutionary America." Wages of Independence: Capitalism in the Early American Republic. Ed. Paul A. Gilje. Madison, WI: Madison House, 1997.

- The Coming of Industrial Order: Town and Factory Life in Rural Massachusetts. Cambridge: Cambridge UP, 1983

Rawick, George P. From Sundown to Sunup; the Making of the Black Community. Westport, CT: Greenwood Press, 1972.

Roediger, David. Towards the Abolition of Whiteness. London: Verso, 1994.

- The Wages of Whiteness: Race and the Making of the American Working Class. London: Verso, 1991.

_. "What if Labor Were Not White and Male? Recentering Working-Class History and Reconstructing Debate on the Unions and Race." International Labor and Working-Class History 51 (1997): 72-95

—. What Was So Great About Herbert Gutman?" Labour/ Le Travailleur 23 (1989): 255-61.

Ryan, Mary P. Civic Wars: Democracy and Public Life in the American City during the Nineteenth Century. Berkeley: U of California P, 1997.

Salstrom, Paul. Appalachia's Path to Dependency: Rethinking a Region's Economic History, 1730-1940. Lexington: UP of Kentucky, 1994.

Saxton, Alexander, "Blackface Minstrelsy and Jacksonian Ideology." American Quarterly 27 (1975): 3-28.

-. The Rise and Fall of the White Republic: Class Politics and Mass Culture in Nineteenth-Century America. London: Verso, 1990.

Scott, Joan Wallach. Gender and the Politics of History. New York: Columbia UP, 1988.

Scranton, Philip. Proprietary Capitalism: The Textile Manufacture at Philadelphia, 1800-1885. Cambridge: Cambridge UP, 1983. 
Slotkin, Richard. The Fatal Environment: The Myth of the Frontier in the Age of Industrialism, 1800-1890. Middletown: Wesleyan UP, 1985.

- Regeneration Through Violence: The Mythology of the American Frontier, 1600-1860. Middletown, CT: Wesleyan UP, 1973.

Smith, Billy G. The "Lower Sort": Philadelphia's Laboring People, 1750-1800. Ithaca: Cornell UP, 1990.

Stansell, Christine. City of Women: Sex and Class in New York 1789-1860. Urbana: U of Illinois P, 1987.

Stedman-Jones, Gareth. Languages of Class: Studies in English Working Class History, 1832-1982. Cambridge: Cambridge UP, 1983.

Stott, Richard B., ed. History of My Own Time, or, the Life and Adventures of William Otter, Sen. Ithaca: Cornell UP, 1995.

-. Workers in the Metropolis: Class, Ethnicity, and Youth in Antebellum New York City. Ithaca: Cornell UP, 1990.

Taft, Philip. The A. F. of L. from the Death of Gompers to the Merger. New York: Harper, 1959.

Thompson, E. P. The Making of the English Working Class. New York: Pantheon Books, 1964.
Ware, Norman. The Industrial Worker, 1840-1860. 1924. Chicago: Ivan R. Dee, 1990.

White, Shane. Somewhat More Independent: The End of Slavery in New York City, 1780-1810. Athens: U of Georgia P, 1991.

Wilentz, Sean. Chants Democratic: New York City and the Rise of the American Working Class, 1788-1850. New York: Oxford UP, 1984.

Winkle, Kenneth. The Politics of Community: Migration and Politics in Antebellum Ohio. Cambridge: Cambridge UP, 1988.

Woodward, C. Vann. The Strange Career of Jim Crow, 3rd rev. ed. New York: Oxford UP: 1974.

Woolacott, Angela. “'All This Is the Empire, I Told Myself': Australian Women's Voyages 'Home' and the Articultion of Colonial Whiteness." American Historical Review 102 (1997): 1003-29.

Frank Towers is an Assistant Professor at Bilkent University, Ankara, Turkey. He received his Ph.D. in History in 1993 from the University of California at Irvine. His research focuses on politics, labor, and race in the midnineteenth century urban South. 